\title{
Elaboration of strategic plans for territory development based on the implementation of investment and construction projects
}

\author{
Elena Akimova ${ }^{1, *}$ \\ ${ }^{1}$ Moscow State University of Civil Engineering, Yaroslavskoe shosse, 26, Moscow, 129337, Russia
}

\begin{abstract}
In the authors' opinion, the most important element to form the territory development strategy is the mandatory inclusion of indices of the investment and construction projects which are implemented within the strategy. The principal problem of the existing system of strategic planning in this country is insufficient accounting of investment and construction projects influence on the strategy of regional development. It significantly holds in check the current business activity and, consequently, the longterm effective development of the territory. Currently the solution of issues connected with the effective territory development is ever more challenging; the complex geopolitical and economic situations force the Russian government to look for new drivers of growth and further development by means of the country internal resource. The main prerequisites of long-term sustainable development of the Russian Federation are: the vast human capital assets, surviving economic, significant territorial and natural resources. However, the tasks of long-term development of the country cannot be solved without the effective system of strategic planning at all levels of administrative-territorial division and clear-cut priorities.
\end{abstract}

\section{Introduction}

The construction industry is critical in economics of any country since it largely determines not only the economic state, but also the employment rate of able-bodied population, possibility to improve quality and the standard of living, decrease the criminality in territories, reduce the number and significance of risk factors in the society, and allows implementation of "healthy home" concept.

The Russian Federation, having a vast quantity of undeveloped backlogs (natural, industrial, labour, etc.) strives to use them expediently for overcoming the challenging economic situation and further sustainable development. To develop the promising territories not only economically, but socially too, a certain balance is necessary between the production development and the social development strategy aimed at provision of comfortable living conditions. This process can be managed by implementing investment and construction projects.

\footnotetext{
* Corresponding author: angela-1309.m@yandex.ru
} 


\section{Materials and Methods}

The Federal Law "On Strategic Planning in the Russian Federation" No. 172-FZ passed on June 28th, 2014 facilitated the development of the comprehensive strategic planning system in this country. The law fixed the unified system of concepts, established clear hierarchy of decision-making levels and periodicity of strategic planning documents preparation, having partially included into it the territorial planning documents too. However, at the present time the territorial planning system is in uncertain state, as it continues to be subjected by Town Planning Code of the Russian Federation too. Duplication of functions does not facilitate the effective implementation of the comprehensive territory development strategy.

Dynamics, structure and scope of construction works carried out in the area characterise the overall development level of the industrial production, related industries of economy, social policy formation, i.e. the investment and construction sector is the main party of social and production investment programmes of the regional economy development. Therefore, the particular significance and practical need is connected with the effective implementation of investment and construction projects (by creating efficient new management mechanisms and updating the existing ones), forecasting and assessing the effectiveness of the projects which shall be oriented to different aspects of the construction sector economy activity.

The critical analysis of existing investment and construction project effectiveness assessment techniques allowed detection of a number of significant drawbacks, including:

- only profit is considered as the ROI index and the additional effect, which cannot always be expressed in monetary terms, is neglected;

- the factor of uncertainty of project implementation consequences is not considered due to general instability of development of events in all living environments;

- the interconnection of investment-construction projects and the strategic territory development planning is not considered.

The task of strategic territory development plans formation on the basis of implementation of investment and construction projects in current continuously changing economic circumstances is ever more topical. A wide range of tasks of theory, methodology, estimation and analysis of the investment and construction project effectiveness in the new economic conditions requires further research.

At the present time, solution of the issues connected with the effective territory development is ever more challenging; complex geopolitical and challenging economic situations force the government to look for new drivers of growth and further development by means of the country internal resources. The main pre-requisites of the long-term sustainable development of the Russian Federation are: vast human capital assets, surviving economic, significant territorial and natural resources. However, the tasks of long-term development of the country cannot be solved without the effective system of strategic planning at all levels of administrative-territorial division and clear-cut priorities of the spatial territory development.

The Federal Law "On Strategic Planning in Russian Federation" No. 172-FZ passed on June 28th, 2014 (hereafter referred to as FZ No. 172) facilitated the development of comprehensive strategic planning system in this country. The law fixed the unified system of concepts, established clear hierarchy of decision-making levels and periodicity of preparation of strategic planning documents, having partially included into it the territorial planning documents also. However, at the present time the territorial planning system is in uncertain state, as it continues to be subjected by Town Planning Code of the Russian Federation too.

The author believes that one of the main issue of the strategic planning system under construction in the Russian Federation is the absence of geographic areas' clear-cut strategic 
territory development plans which take into consideration the interests of all parts of this process, including investors, society and the state.

Construction is one of the basic industries of the country providing about 7\% as GDP contribution [1]. According to the data of Federal State Statistics Service of the Russian Federation, the total volume of investments in the construction industry over recent years is over 50\% of the total volume [2]. The difficult situation in Russian economy in 2014-2015 has exerted adverse effect on the basic indices of the investment and construction activity. In 2015, 298.1 thousand buildings with the total area of 107.6 million sq. $m$ were commissioned, the total volume of the executed construction works amounted to 5,981.7 billion Russian roubles, and for the first time since 2009 it decreased (-4.5\%) with regard to data of the previous period. The negative dynamics according to the results of 2014 year was noted in relative share of investments in the construction sector of the cumulative investment - decrease by $0.3 \%$.

The driver of the construction industry is residential construction (Figure 1), in 2014 the record high amount of flats was commissioned - over 1.1 million. It is evident, that crisis phenomena in economy as on the research data have not almost influenced the inertial levels of residential construction.

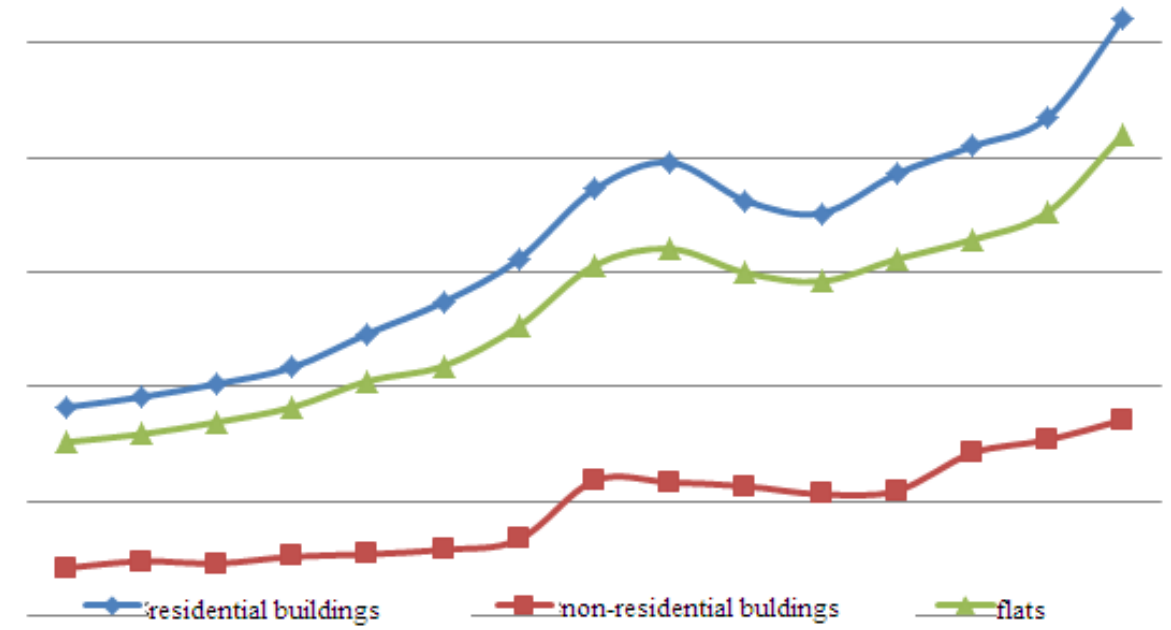

Fig. 1. The total area of commissioned facilities.

According to estimates of the Centre for Market Investigations of Higher School of Economics [3], the construction industry in Q3, 2015 remained in the state of continuous sluggish economic recession without any evident signs of exit from this phase of economic cycle. The importance of support and further development of construction activity in difficult economic conditions was repeatedly emphasised by the prime minister and members of the government of the Russian Federation.

Historically the significant regional differentiation of the investment and construction activity indices is observed, it is mostly connected with the remaining self-sustainability of economic and social systems of territories. The leader among regions in terms of residential house construction in 2014 was Moscow Region - 8255.1 thousand sq. $\mathrm{m}$ of the total area over $10 \%$ of the total volume, the outsider was the Chukotka Autonomous Region with the amount of 1.8 thousand sq. $\mathrm{m}$ of the total area of commissioned residential houses. The difference in indices between regions is more than 4500 -fold. 
In terms of the total volume of investments in the fixed capital in 2014 the leader was the Tyumen Region (1690314.6 million roubles), which overtook Moscow (1477372.1 million roubles), the Krasnodar Territory (693208.1 million roubles) and the Moscow Region (594494.5 million roubles). The minimum indices were achieved in the Chukotka Autonomous Region - 6616.2 million roubles.

\section{Results}

Analysing Russian scientists' research papers on the issues of determining the project effectiveness, it can be stated that papers mainly consider the issues of assessing the economic effectiveness, and additional effect, as well as no long-term territory development forecasts or possible adverse consequences of such project implementation are not considered; scientifically substantiated strategic planning of territory development based on implementation of the investment and construction project is not considered, the result of which should be improvement of the general level of local population living.

To this day the task of assessing the investment and construction project effectiveness is in the focal point of scientific and applied developments of Russian and foreign researchers, since it is undoubtedly topical.

Forecasting and assessment of an investment and construction project effectiveness includes calculation of the economic effectiveness indices and determination of indices of the additional effect connected with changes of parameters of the strategic project implementation territory development planning.

In this regard, the author suggests a three-level economic-mathematical model of effectiveness assessment of an investment and construction project [4,5] in the territory development strategy elaboration system:

Level 1 - preliminary estimate of the effectiveness under conditions of the external environment impact uncertainty;

Level 2 - selection of a project implementation strategy taking into consideration the preliminarily performed effectiveness calculations;

Level 3 - carrying out the project effectiveness estimate calculations taking into consideration the accepted strategy.

The sequence of the levels represented in the model is non-casual; elements are interdependent and have direct links with each other, without existence of the first level no further levels can exist.

The unit of preliminary forecast estimation of the investment-construction project effectiveness includes three modules:

1. Monitoring of the current state of territory development social-economic indices, preliminary calculation of the investment and construction project effectiveness indices.

2. The procedures allowing analysing and determining the predictive estimate of the investment-construction project state under conditions of uncertain character of the external environment impact.

3. The estimates of the investment and construction project state under continuously changing conditions of the external environment.

In the period of uncertain economic situation in the country due to volatility of national currency exchange rate, the economic effectiveness calculation of an investment and construction project shall be carried out with due account for factors of uncertainty and incompleteness of information on project implementation, based on the commercial risk and connected with continuous change of the currency exchange rates which, respectively, results in a change of prices for raw and other materials, fixed assets, i.e. factors influencing the project cash flow change. Therefore it is necessary to carry out procedures allowing 
analysing and determining the predictive estimate of the investment-construction project state under conditions of uncertain character of the external environment impact [6].

Investors, assessing economic effectiveness of a project, take account of the influence of scheduled activities on the project effectiveness index components from its implementation costs and forecast the possible project result. To that end, the predictive effectiveness estimate is carried out at the stage of the scheduled activities implementation for assessment of possible results and their deviations from target indices in order to organise some additional control effects on the indices to eliminate deviations from target indices [7].

The algorithm of forecasting and generation of control actions in the form of economic procedures and assessment of their effectiveness is shown in Figure 2.

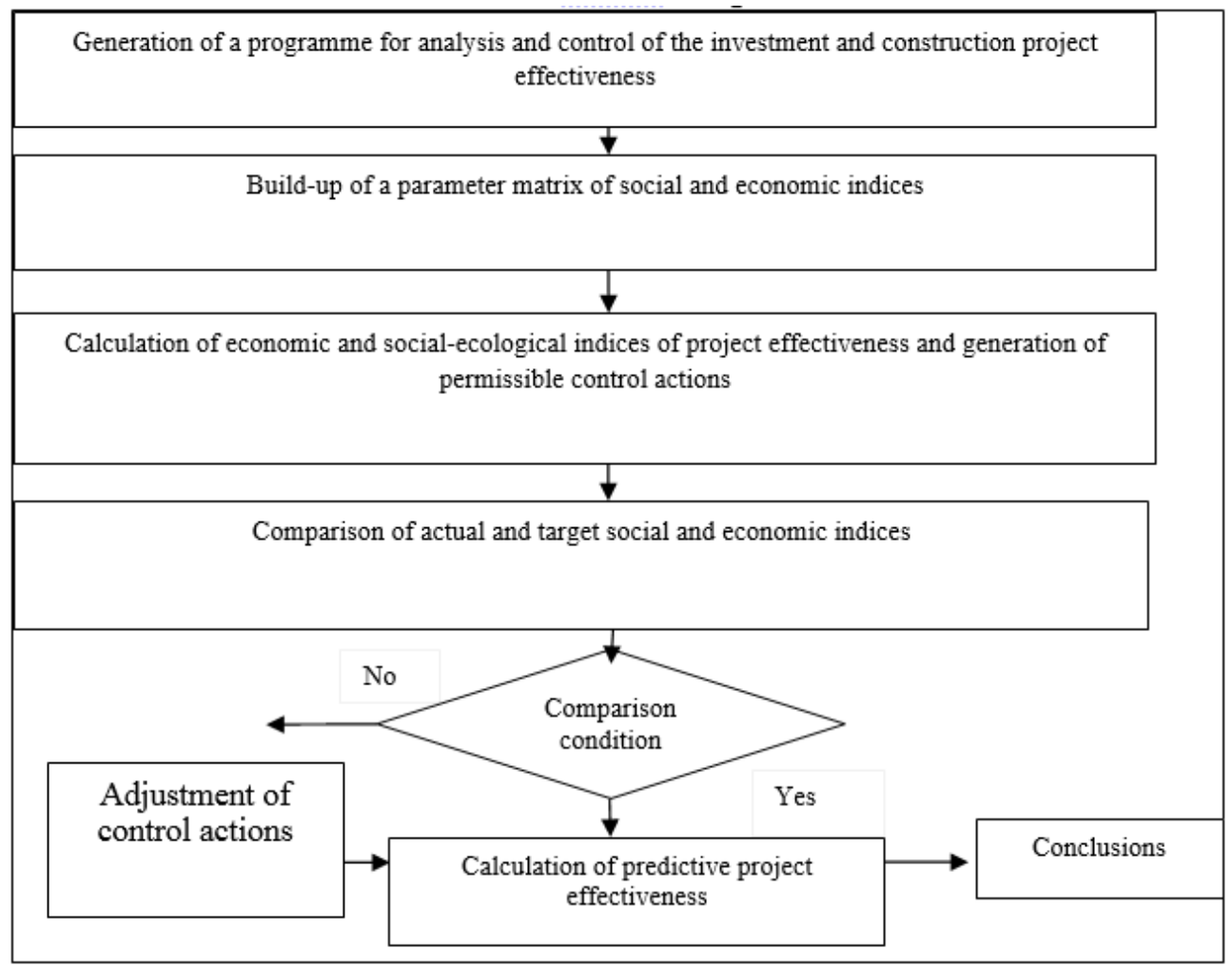

Fig. 2. The algorithm of generation of control actions on the investment and construction project effectiveness.

The presented algorithm allows adequate assessing of the state of an investment and construction project under current conditions of uncertainty and absence of clear-cur plans for further development.

The unit for selection of the optimal investment and construction project implementation strategy which is based on the predictive estimate of the economic project effectiveness indices. The unit consists of two modules:

1. Analysis of various variants of the investment and construction project implementation strategy, selection of the optimal directions for achieving the specified targets.

2. Selection of a strategy with maximum predictive effectiveness.

The innovation and construction project strategy is a system of long-term investment activity objectives determined by general tasks of its development of the territory, as well as selection of the most effective ways of their achievement. The strategy selection begins with the assessment of its current position for business planning and preparation of a 
business plan which provides detailed explanations how the project will be managed so that to ensure its profitability, as well as return on investments. In accordance with changing economic conditions, a business plan analysis and adjustment are necessary for creation of an effective managerial strategy and achievement of the maximum project effectiveness [8].

To achieve the maximum positive effect, it is necessary to make a reasonable decision on the most effective strategy variant. The optimal investment and construction project implementation strategy selection algorithm can be outlined as a flow chart (see Figure 3 ).

\section{Characteristic of strategies under consideration}

Assessment of the current project position

Business planning procedure

Adjustment of the plan in accordance with changing conditions

Selection of strategies for achievement of the maximum social and economic effectiveness

Development of general targets of the investment and construction project

Determination of particular targets for the set time interval

Determination of the ways to achieve the specified targets

Control over the process of achieving all specified targets

Comparison of planned and actual economic and social-ecological indices

Fig. 3 Algorithm for selection of the investment-construction project strategies.

The unit of predictive estimate of the project effectiveness taking into consideration the operational strategies includes two modules:

1. Estimation of the investment and construction project state by the effectiveness indices under conditions of the uncertain character of the external environment impact with due allowance for operational strategies.

2. Comparison with the initial predictive estimate.

The forecast carried out at the stage of the scheduled activities implementation, using the presented modelling flow-chart, provides estimation of possible results and their deviations from plan indices in order to organise additional control actions on indices to eliminate deviations from the planned indices. The predictive estimate is carried out by ranging criteria in order of their importance for achieving the optimal effect. 
Using the predictive description of the project development by means of setting probabilistic/fuzzy values of respective cash flows generation, investors consider optimistic and pessimistic predictive scenarios of the economic situation development [9].

The investment and construction project effectiveness estimate shall be carried out based on the developed system of indicators which represent quantitative indices and qualitative characteristics. Comparison of the current values of target indicators with the values set by the programme from the over the reporting period will be the value of deviation (upward or downward) from the target $[10,11]$.

Table 1. Region development indices.

\begin{tabular}{|c|c|}
\hline Index name & Formula \\
\hline $\begin{array}{l}\text { Unemployment } \\
\text { rate }\end{array}$ & $\begin{array}{l}\mathrm{K}_{u r}=\frac{\mathrm{K}_{u r 1}}{\mathrm{~K}_{u r 2} \text {, where: }} \\
\mathrm{K}_{u r} \text { - coefficient which characterizes the unemployment rate change in the } \\
\text { area under study as compared to the average value over the district; } \\
\mathrm{K}_{u r 1} \text { - unemployment rate in the area under investigation; } \\
\mathrm{K}_{u r 2 \text { - unemployment rate (on average) over the district. }}\end{array}$ \\
\hline Salary level & $\begin{array}{l}\mathrm{K}_{s l \text { зп }}=\frac{\mathrm{K}_{s l 1}}{\mathrm{~K}_{s l 2}} \text {, where: } \\
\mathrm{K}_{s l} \text { - coefficient which characterizes change in salary value in the area } \\
\text { where the project was implemented as compared to the average salary level in } \\
\text { the district; } \\
\mathrm{K}_{s l 1} \text { - average salary level in the geographical area where the project was } \\
\text { implemented; } \\
\mathrm{K}_{s l 2} \text { - average salary level in the district or another compared area. }\end{array}$ \\
\hline $\begin{array}{l}\text { Newly created } \\
\text { jobs }\end{array}$ & $\begin{array}{l}P=\frac{V \times d}{C}, \text { where: } \\
P \text { - number of newly created or reconstructed jobs; } \\
\text { V - volume of investments; } \\
d \text { - share of investments directed for organisation of jobs; } \\
\text { C- average cost of one job commissioning. }\end{array}$ \\
\hline $\begin{array}{l}\text { Provision of } \\
\text { pre-school } \\
\text { institutions and } \\
\text { schools }\end{array}$ & $\begin{array}{l}I_{p s}=\frac{\left(I_{p s 1}-I_{p s 2}\right)}{I_{p s 1}} \text {, where: } \\
I_{p s^{-}} \text {deviation in the level of provision of pre-school institutions and } \\
\text { schools; } \\
\mathrm{I}_{\text {ps 1- coverage of children with pre-school institutions and schools on }} \\
\text { average in the district (percentage); } \\
I_{p s 2^{-} \text {- coverage of children with pre-school institutions and schools in the }} \\
\text { Area under investigation (percentage) }\end{array}$ \\
\hline $\begin{array}{l}\text { Provision of } \\
\text { health care } \\
\text { institutions }\end{array}$ & $\begin{array}{l}I_{h c i}=\frac{\left(I_{h c i 1}-I_{h c i 2}\right)}{I_{h c i 1}} \text {, where: } \\
I_{h s i^{-}} \text {deviation in the level of provision of health care institutions in the } \\
\text { region; } \\
I_{h c i 1} \text { - number of hospital accommodations per } 10,000 \text { people on average in } \\
\text { the region; } \\
I_{h c i 2}-\text { number of hospital accommodations per } 10,000 \text { people on average } \\
\text { in the district where the project is implemented. }\end{array}$ \\
\hline $\begin{array}{l}\text { Provision of } \\
\text { the territory } \\
\text { with }\end{array}$ & $I_{e}=\frac{\left(I_{e 1}-I_{e 2}\right)}{I_{e 1}}$, where: \\
\hline
\end{tabular}




\begin{tabular}{|c|c|}
\hline Index name & Formula \\
\hline $\begin{array}{l}\text { engineering } \\
\text { infrastructure } \\
\text { facilities }\end{array}$ & $\begin{array}{l}I_{e} \text {-deviation in the level of provision of engineering infrastructure facilities } \\
\text { in the area; } \\
I_{e 1^{-}} \text {the number of engineering infrastructure facilities per person, on } \\
\text { average in the district; } \\
I_{e 2^{-}} \text {the number of engineering infrastructure facilities per } 1 \text { person, on } \\
\text { average in the area under consideration; }\end{array}$ \\
\hline $\begin{array}{l}\text { Provision of } \\
\text { the population } \\
\text { with housing }\end{array}$ & $\begin{array}{l}I_{p}=\frac{\left(I_{p 1}-I_{p 2}\right)}{I_{p 1}} \text {, where: } \\
I_{p^{-}} \text {deviation in the level of provision of population with comfortable } \\
\text { housing; } \\
I_{p 1} \text { - comfortable housing area per } 1 \text { person, on average in the district; } \\
I_{p 2} \text { - comfortable housing area per } 1 \text { person, on average in the area under } \\
\text { investigation. }\end{array}$ \\
\hline
\end{tabular}

Population size of the area, including those who receive material goods and social services, can be used as the main index when investment and construction project effectiveness assessment. Determination of the investment and construction project effectiveness shall include the analysis of the official statistical data for each key index. The change of the effect indices can be presented in the form of absolute values - coefficients characterising dynamics of changes in relation to the average values over the compared area.

The investment and construction project effectiveness is characterised by the whole system of indicators reflecting ration of expenditures incurred and obtained results; it reasonable carries out the analysis of behaviour of indicators over the entire project life time. The main index of the investment and construction project effectiveness (PE) can be presented as follows:

$$
\mathrm{PE}_{(\mathrm{E} 1 \mathrm{E})_{\mathrm{i}}}=\Delta \mathrm{I}_{(\mathrm{I} 1 \mathrm{E})_{\mathrm{i}}} / \sum_{\mathrm{i}=1}^{\mathrm{n}} \mathrm{Z}_{\mathrm{i}}
$$

Where $\Delta \mathrm{I}_{(\mathrm{C}-\mathrm{E})_{\mathrm{i}}}$ is the change of indicators which characterize the area economic situation,

$\sum_{\mathrm{i}=1}^{\mathrm{n}} \mathrm{Z}_{\mathrm{i}}$ - the sum of expenditures incurred during the investment and construction project implementation,

$\mathrm{n}$ - project implementation stage.

Calculation of the economic component effectiveness is usually carried out upon completion of the project. The table below shows main indices reflecting the economic situation in the region.

Based on the obtained results, it is possible to calculate the effect obtained as a result of implementation of an investment and construction project determined as:

$$
C_{i}=\left(K_{u r}+K_{s l}+P+I_{p s}+I_{h c i}+I_{e}+I_{p}\right) \times V_{i}
$$

Once the calculated effect value is calculated, it is possible to determine the ICP effectiveness (E) and its contribution to the territory development strategy elaboration system: 


$$
\mathrm{E}=\frac{\mathrm{C}_{\mathrm{a}}}{\mathrm{C}_{\mathrm{e}}}
$$

Where: $C_{e}$ - expected value of the effect, $C_{a}$ - achieved value of the effect.

The proposed system of indicators (Table 1), calculation of the integral life quality indicator and social effect indicator allows carrying out monitoring the social sphere behaviour which is necessary for elaboration of the project development strategy, more accurate definition and adjustment of the specified tasks and performed activities over a definite period at each stage of the investment project life cycle $[12,13]$.

Thus, forecasting the investment-construction project effectiveness in the territory development strategy elaboration system can be carried out on the basis of economic and mathematical modelling which includes the following main stages:

- elaboration of scheduled procedures for project implementation;

- assessment of procedures under conditions of incomplete information and economic situation uncertainty;

- selection of maximum effective indices at each project implementation stage;

- assessment of the final project effectiveness in order of adequacy of the obtained effect value.

\section{Discussion}

The following features shall be taken into consideration during compilation of a systematic scheme of the investment-construction project effectiveness assessment:

1. Duration and stages of the investment and construction project. When execution of the main project stages, time-frames shall be established for implementing the main types of works, on which the results of the investment and construction project and the effectiveness of their achievement depend. They can include:

- main stages of project works performance;

- project cash flow;

- timing budget for project implementation;

- financial, labour and technical resources.

2. Expected indices shall be formulated at the project design stage taking into consideration optimistic and pessimistic scenarios of the economic situation development.

3. Assessment of costs and results at determination of the investment project effectiveness shall be carried out over a definite calculation period, the duration of which is accepted taking into consideration project specificity, project life cycle stages duration and investor requirements.

4. When assessing the effectiveness of projects, it is necessary to take into consideration the project implementation consequences - emergence of external effects which can be either positive, or negative. When a negative external effect emerges, the procedures to eliminate the negative consequences of the project shall be developed.

5. The investment and construction project comprises different project parties with interests that do not coincide with each other, so it is necessary to take into consideration interests and opinions of all project parties at project effectiveness assessment in such a way, that the ratio of effectiveness was optimal. Using the developed algorithm of investment project effectiveness assessment, it is necessary to analyse and estimate the effectiveness of conducted procedures and, if required, introduce amendments in the procedure implementation programme to achieve the maximum final effectiveness. 
6. Thereafter the investment and construction project implementation experience shall be taken into consideration during designing of investment projects, and as regards creation and update of the indices database.

The comparison of integral life quality indicators at different project life cycle stages is a project management effectiveness index. If the obtained results differ from the forecast, it is necessary to introduce amendments in the investment and construction project implementation programme to achieve the maximum effect.

\section{References}

1. Federal Law On investment activity in the Russian Federation carried out in the form of capital investments, Rossiyskaya Gazeta, 39 (1999)

2. Federal Law On participation in the shared construction of apartment buildings and other real estate facilities and on introduction of amendments to some legislative acts of the Russian Federation, Rossiyskaya Gazeta, 31 (2004)

3. The concept of long-term social and economic development of the Russian Federation for the period till 2020

4. D.V. Knyazev, Management of economic systems: electronic scientific journal, $\mathbf{7 3}$ (2015)

5. I.V. Lipsits, V.V. Kossov, Investment project: methods of preparation and analysis (BEK, Moscow, 1996)

6. A.A. Tyutchenko, Formation of the strategy for financing investment and construction projects (2010)

7. Y.V. Yakovlev, Problems of modern economics (2010)

8. Y.S. Prokhorova, I.V. Karakozova Economy and Entrepreneurship 6(3), 608-613 (2015)

9. I.V. Karakozova, Economics and Entrepreneurship 5(2), 950-954 (2014)

10. L. Chiquier, M. Lea, Structure and Evolution of Housing Finance Systems (World Bank, 2009)

11. Morsingand, Schultz, Corporate social responsibility communication (Business Ethics, 2006)

12. E.M. Akimova, D.V. Knyazev, International Journal of Applied Engineering 10, 18 (2015)

13. D.V. Knyazev, Economy and Entrepreneurship 8, 889-893 (2014) 